\title{
ORIGIN OF OIL IN THE WILMINGTON FIELD IN CALIFORNIA.
}

\author{
Karl Terzaghi \\ Harvard University.
}

The Wilmington Field is located on Terminal Island south of Los Angeles, California. The oil-bearing strata belong to the Miocene and the lower Pliocene. The lowest oil-bearing stratum is separated from the underlying basement (Jurassic metamorphic schists) by an unconformity. A description of the oil fields has been published by Gilluly and Grant (1943, p. 401-529).

The oil-bearing strata, with a total thickness of about 4.000 feet, constitute a gentle brachy-anticline which is subdivided by several cross-faults into blocks. The unconformity at the base of the oil-bearing formations is located at a depth of about 6.000 feet. The oil-bearing strata consist of layers of sand with a total thickness of about 1.500 feet, separated from each other by layers of siltstone.

Both the oil sands and the siltstone have the grainsize characteristics of wind-laid sediments. The grainsize curves of the sand ressemble those of dune sands and those of the siltstone have the appearance of the grainsize curves of dune sand with a slight admixture of loessial material. However, in contrast to the particles of wind-laid deposits formed on the surface of continents, the grains of the oil-bearing sands and of the siltstones are angular to subangular. In some of the layers small pieces of gravel have been encountered.

According to Dr. D. A. McNaughton of Los Angeles, California, the depth of water in which the oil sands were deposited increased from about 200 feet for the lowest oil-bearing stratum to about 5.000 feet for the oil sands close to the upper boundary of the oil-bearing formations. It is inconceivable that sand grains with a size up to $0.3 \mathrm{~mm}$ could be transported by ocean currents to a distance from the shore where the depth of water amounts to several thousand feet. Practically all the sediments would have been deposited on the continental shelf where the depth of the water is less than 600 feet. Therefore it appears that the material was transported by the wind.

Storms which can transport sand to a distance of tens of miles trom the shore line are exceptional. However, the rate of sedimen- 
tation was extremely slow. According to Dr. Mc Naughton's estimate it decreased from one foot in 2.700 years for the oldest Miocene sediments to one foot in 5.500 years for the Pliocene ones. Considering this rate of sedimentation one exceptional storm per century would suffice to account for the existance of the sediments.

The aeolian origin of the sediments accounts for the conspicuous absence of clay in the sediments, and the low rate of sedimentation combined with the deposition in deep water may account for the presence of the oil in the sands, because the deposition of the sand occurred at a very much slower rate than the production of organisms in the plankton zone located above the seat of sedimentation.

According to James A. Johnston (1939, vol. 17, p. 1.004), the plankton is produced at a rate of about $0.2 \mathrm{lbs}$ of dry hydro-carbons per square foot a year which amounts to 3500 tons in 15 million vears, the length of the period during which the oil sands were deposited. Yet the quantity of oil stored up in the oil sands hardly exceeds 8 tons per square foot or less than 0.23 percent of the quantity of hydro-carbons which rained down, during the period of sedimentation, from the plankton zone onto the seat of sedimentation in the form of dead organisms.

\section{RESUMO}

No presente trabalho, o autor trata da formação de campo petrolifero que se teria formado às expensas de organismos planctônicos, misturados com areia das dunas, material esse que teria sido transportado pelo vento.

Refere-se, assim, o autor, ao campo petrolifero de "Wilmington", situado na Ilha Terminal, ao sul de Los Angeles, California. Esse campo, que já fôra descrito, em 1943, por Gilluly \& GRANT, faz parte do Mioceno e do Plioceno inferior, achando-se separado dos schistos Jurássicos metamórficos, por uma discordância localizada a 6.000 pés de profundidade. O conjunto das camadas petroliferas alcança espessura de 1.500 pés, sendo cada uma delas separada das outras por estratos do "siltstone" (siltito). O tamanho dos grãos, nos dois típos de rochas, é o de depósitos eólicos, mas, ao contrário do que acontece em depósitos sub-aéreos, esses grãos são angulosos ou sub-angulosos.

De acôrdo com McNaughton, esses depósitos se teriam formado em profundidade crescente, de 200 a 5.000 pés; esse fato, relacionado com as dimensões dos grãos, leva a crer que o material tenha sido transportado pelo vento. A sedimentação deu-se longe da costa, de maneira muito lenta, provavelmente em consequência de tempestades 
de excepcional intensidade. $O$ petróleo teria sido produzido por organismos planctônicos que se teriam misturado com areia das dunas, sendo a velocidade da sedimentação desta, muito menor. Os cálculos indicam que foram armazenados somente $23 \%$ dos hidrocarbonetos que cairam sôbre a areia de sedimentação, sob a forma de organismos mortos.

M. V.

\section{BIBLIOGRAFIA}

GILLULY, J., \& GRANT, U. S., 1943 - Subsidence in the Long Beach Harbor Area, California. Bull. Geol. Soc. of Am., vol. 60, p. 401-529.

JOHNSTON, J. A., 1939 - Encyclopedia Britannica, 14th edition, vol. 17, p. 1004. 